\title{
COMMENTARY
}

\section{S. 1232-A LATE ENTRY IN THE RACE FOR MALPRACTICE REFORM}

\author{
Clark C. Havighurst* and Thomas B. MetzlofF**
}

\section{INTRODUCTION}

The field is growing in the race to take federal action to reform the law of medical malpractice. ${ }^{1}$ Most of the entries are running under similar Republican colors, however. ${ }^{2}$ They also bear a family resemblance in being generally concerned with such things as expanding the use of alternative methods of dispute resolution, limiting the amount and form of damages, shortening statutes of limitations, and altering the rule of joint and several liability. To be sure, each proposal features a different combination of specific reforms or a different means of getting them adopted by the states. But none of the initial entries in the federal race has generated great excitement among followers of the malpractice sport.

The latest entry in the race for federal malpractice reform, however, is a horse of a more interesting color. S. 1232, the "Medical Injury Compensation Fairness Act of 1991," was introduced on June 6, 1991, by Senator Pete V.

Copyright $\odot 1991$ by Law and Contemporary Problems

* William Neal Reynolds Professor of Law, Duke University. Mr. Havighurst also serves as a Director of the Private Adjudication Center, Inc., which provides alternative dispute resolution services to malpractice litigants.

** Associate Professor of Law, Duke University. Mr. Metzloff also serves as the Director of the Private Adjudication Center's Medical Malpractice Program.

The authors discussed earlier drafts of the legislation analyzed in this commentary with Senator Domenici's staff during the drafting stage.

1. See, for example, Health Care Liability Reform and Quality of Care Improvement Act of 1991, S 1123, 102d Cong, 1st Sess (May 22, 1991) (proposal of the Bush administration, introduced by Sen. Orrin Hatch); Ensuring Access Through Medical Liability Reform Act of 1991, S 489, 102d Cong, 1st Sess (February 26, 1991) (proposal of the American Medical Association, introduced by Sen. Orrin Hatch); Medical Malpractice Dispute Resolution Act of 1990, HR 4566, 101 st Cong, 2d Sess (April 19, 1990) (introduced by Rep. Nancy Johnson).

2. None of the bills cited in note 1 has a Democrat as a co-sponsor. Democrats' support of malpractice reform has been limited, partly because of their preference for more sweeping health care reform. Republicans, on the other hand, are content to proceed piecemeal, on the theory that lowering malpractice risks and costs can make both private coverage and expansions of public programs more affordable, thus addressing the problem of inadequate insurance coverage of the population. 
Domenici (R., New Mexico). ${ }^{3}$ This bill would go further than any other current proposal in using federal power directly to change the legal rights of health care consumers. One of its purposes is to impose limits on the damages recoverable in all malpractice cases arising out of care subsidized directly or indirectly by the federal government. The bill's most radical feature, however, is its bid to force all such malpractice cases out of the courts and into alternative forums for resolving disputes. This threatened federal entry into a sensitive area of plaintiffs' rights and state concern is certain to be controversial.

Although S. 1232 would be aggressively prescriptive of consumer rights in the foregoing respects, the bill is also notable for its forbearance in not using federal power to prescribe the details of all the reforms it would initiate. It would not, for example, finally specify the actual design of alternative dispute resolution ("ADR") mechanisms, thus opening the field to experimentation by competing ADR services and ultimately to private choice. Similarly, in addressing the vagueness and inefficiency of the legal standard of care traditionally employed in judging negligence in malpractice suits-a problem that previous legislative initiatives have rarely addressed at all-the bill would not mandate any particular change in the legal standards currently appearing in state law. Instead, it would simply indicate the receptivity of the federal government to alternative standards that might be independently specified either for federal health care programs or in private contracts between consumers and health care providers. Thus, even though the purpose of $\mathrm{S}$. 1232 is to effectuate quite radical changes in a dysfunctional legal system, its method is not to legislate all such changes but to establish a new framework within which both procedural and substantive rights could evolve through the efforts and interaction of the parties affected.

We view S. 1232 as a highly constructive entry in the race to find solutions to some serious problems in American health care. ${ }^{4}$ On the one hand, the bill is notable as an extreme assertion of federal authority, which it exercises by deeming (or requiring) certain private "agreements" to exist as preconditions to the enjoyment of valuable federal benefits. In our view, however, an even more significant feature of the bill is the considerable room it leaves for parties to such mandatory "agreements" and providers of ADR services to introduce reforms of their own design, thus altering by private contract procedural and substantive rights that have heretofore been generally

3. S 1232, 102d Cong, lst Sess (June 6, 1991). Senator Domenici's effort has been publicly endorsed by C. Everett Koop, M.D., former Surgeon General of the United States. See Pete V. Domenici \& C. Everett Koop, Sue the Doctor? There's a Better Way, NY Times A25 (June 6, 1991).

Sections 3 and 6 of S 1232 are set forth in the Appendix. These and other sections are cited parenthetically in this article. Section 4 of the bill is omitted because it so closely corresponds in structure and substance to section 3, while applying to a different category of malpractice cases. Unless otherwise indicated, cited subdivisions of section 3 have counterparts in section 4 .

4. Our general views on some of the topics discussed in this article appear in our respective individual contributions to this symposium. See Clark C. Havighurst, Practice Guidelines as Legal Standards Governing Physician Liability, 54 L \& Contemp Probs 87 (Spring 1991); Thomas B. Metzloff, Resolving Malpractice Disputes: Imaging the Jury's Shadow, 54 L \& Contemp Probs 43 (Winter 1991). 
prescribed by the legal system alone. This move to endow the private sector with the freedom to create new procedures and different legal relationships is emphasized in much of the discussion that follows. Because the paradigm that has previously dominated decision making on medical care issues in the United States has generally curtailed the role of consumer choice, ${ }^{5}$ the explicit recognition and exploitation of the contractual character of health care in Senator Domenici's bill should be especially highlighted. Indeed, the idea of expanding the effective realm of private choice might be usefully incorporated in federal proposals that seek more general reform of American health care.

Unlike other federal malpractice reform proposals, S. 1232 would bypass state law in several important respects, directly imposing a federal solution in an area that has traditionally been governed solely by the states. There are several reasons why Congress might override federalism concerns and take preemptive federal action. First, Congress might perceive that malpractice law raises health care costs that the federal government bears directly through its own financing programs or indirectly through tax subsidies to the private sector. Congress might also believe that national uniformity is necessary in order that some federal beneficiaries do not enjoy more extensive (and expensive) tort rights than others solely by virtue of their place of residence. ${ }^{6}$ Moreover, some members of Congress might appreciate that the attempts made in other proposals to coerce the states to incorporate federally prescribed reforms in state legislation are hardly less offensive to federalism than direct preemption. ${ }^{7}$

S. 1232 divides patients and providers into three categories for purposes of prescribing or influencing their future legal rights and responsibilities. In the first category are persons who receive or provide care that is paid for directly by the federal government. The second category comprises everyone engaged in health care arrangements the cost of which is a tax-deductible business expense for a private employer. The third category is everyone else. Because the federal government's relationship to the health care transaction differs in the three cases, they are addressed in separate sections of the bill.

5. See generally Clark C. Havighurst, The Professional Paradigm of Medical Care: Obstacle to Decentralization, 30 Jurimetrics J 415 (1990).

6. Congress might also wish that its payments to providers did not have to be adjusted to reflect geographic differences in malpractice climates. See Physician Payment Review Comm'n, 1991 Annual Report to Congress 71-89 (1991) (discussing adjustments to physician fee schedule to reflect malpractice expense). Uniform legal rules do not necessarily yield uniform malpractice costs, however, because of other variables affecting the frequency and severity of claims.

7. The Bush administration's bill ( 1123 , cited in note 1) would deny Medicaid payments to states that do not adopt its reforms. In addition to intruding upon state sovereignty, this method of achieving the federal purpose holds hostage the state's Medicaid beneficiaries, making them innocent pawns in a game in which they have little to gain. 
With respect to substantive matters, however, the first two categories are treated almost identically.

Section 3 of S. 1232 applies to "any person accepting or providing health care to be paid for, in whole or in part, directly or indirectly, with funds made available under . . . any ... Federal Act."8 All patients and providers thus reached by section 3 "shall be deemed to have agreed to participate in the Federal medical dispute resolution program established under this Act for the purpose of fairly and quickly resolving claims against health care providers for personal injury arising from care rendered under [any such Federal Act]." Participation in the "Federal medical dispute resolution program" has several consequences.

The most important reform that would be wrought by the dispute resolution program spelled out in section 3 of the bill is a requirement $(\S \S 3(\mathrm{~b})(1)$, (5)) that all covered malpractice claims must be submitted for final resolution (subject to only limited appeal rights ${ }^{9}$ ) to a public or private dispute resolution service certified by the Secretary of Health and Human Services (HHS). The bill sets forth basic procedures for filing claims $(\S \S 3(\mathrm{~b})(2)-(4))$ and incorporates state statutes of limitations while also introducing its own eight-year statute of repose $(\S 3(\mathrm{c}))$. Later discussion explores the dimensions and implications of the procedural revolution that these and other provisions of the bill would accomplish.

The only substantive reforms that would be effected directly by the bill are the limits it would impose on the damages that can be recovered on a malpractice claim that is subject to its terms $(\S 3(\mathrm{e}))$. Here, however, the bill does not differ much from several other pending proposals or from reforms that have been adopted by a number of state legislatures. Noneconomic damages would be capped at $\$ 250,000$ (unindexed) or at any lower level provided in state law. The bill also provides for deducting amounts receivable from collateral sources-without any exception for, say, victim-purchased life, disability, or health insurance but with subrogation rights of collateral sources apparently preserved. ${ }^{10}$ Whenever the total damages awarded exceed $\$ 100,000$, amounts intended to cover future expenses or losses would have to come in the form of periodic payments. In a unique provision, the bill would allow the award of punitive damages above the cap on noneconomic damages, but only if they are payable to the state (not the claimant) pursuant to a state

8. The apparent intention is not only to reach care covered by the Medicare and Medicaid programs but also to affect patient/provider relationships established in the federal employees health benefits program, in facilities maintained for veterans, in federally supported community health centers, and under other federal health care initiatives.

9. The limited appeal rights specified in the bill $(\S 3(\mathrm{~b})(5))$ are adapted from the Federal Arbitration Act. 9 USC $\$ 10$ (1991).

10. The bill specifies that anyone suing over an injury (including a subrogee or a spouse suing for loss of consortium) would be bound by the injured patient's supposed agreement to arbitrate the claim $(\$ 3(\mathrm{a}))$. 
plan to use them in "monitoring, disciplining, and educating health care providers." The bill says nothing about joint and several liability."

Although section 3 of S. 1232 speaks of providers and patients having "agreed to participate in the Federal medical dispute resolution program," such supposed agreements are obviously not voluntary in any meaningful sense. Comparable compulsion also appears in the bill's method of reaching care rendered under privately financed health care plans. Here Congress's constitutional authority springs not from its power to condition federal spending but from its power to tax. ${ }^{12}$ Section 4 of the bill would amend section 162 of the Internal Revenue Code of $1986^{13}$ in such a way as to disallow an employer's tax deduction for the cost of an employee health benefits plan "unless the employees covered by such plan have entered into agreements" that create a legal regime almost identical to the dispute resolution program created in section 3 of the bill. ${ }^{14}$ Thus, provision would have to be made for ADR and for limiting damages as outlined above.

The Domenici bill reflects a preference for tying the bill's requirements to the employer's tax deduction over the alternative approach of attaching conditions to the exclusion of employer-paid premiums from the taxable income of employees. Although the latter approach would have allowed employees to decide individually whether to accept the new arrangement, the approach chosen may be more attractive politically because it would not so overtly coerce employees to accept a cutback of what many of them perceive to be valuable rights. Employers, however, despite approving the reform objectives of the bill, have restrained their enthusiasm for it largely because it shifts the political burden to them in dealing with their workers. ${ }^{15}$ Another reason for the choice may have been a belief that it would ensure wider adherence to the new regime. But the alternative approach of conditioning employee tax benefits might actually reach farther because it would encompass the many employees of tax-exempt employers.

11. In this connection, we would recommend inserting the following new paragraph in the subsection on damages $(\S 3(\mathrm{e}))$ :

(4) in a case where the claimant has previously settled voluntarily with a party who is

jointly and severally liable for the injury, the damages for such injury awarded against a

second party liable for the injury shall be apportioned according to the degree of that

party's fault as expressly determined in resolving the dispute.

Because this provision would not abolish joint and several liability, a plaintiff would not have to sue every possible tortfeasor or establish the degree of responsibility of each negligent party. But neither could a plaintiff hope to settle with one party and then recover full damages, less the amount of the settlement, from other tortfeasors.

12. We have not addressed the constitutional questions that might be raised concerning the bill, preferring to address the policy issues alone.

13. Many tax experts would probably object in principle to using the tax code to accomplish such substantive policy objectives. Nevertheless, the bill's approach may accomplish two tactical objectives-highlighting the large federal tax subsidy to private health plans and obtaining a hearing before the Senate Finance Committee rather than the possibly less receptive Committee on Labor and Human Resources.

14. See note 3 .

15. Letter from Mary Jane England, President, Washington Business Group on Health, to Senator Domenici, May 20, 1991 (copy on file with authors). 
Although S. 1232 does not attempt to mandate acceptance of the new regime by those persons whose health care is not subsidized by the federal government, it does condition a provider's general eligibility to participate in Medicare and Medicaid on the making of "a good faith effort to enter into agreements with [such persons] . . . to provide for the resolution of medical injury claims" ( $\$ 5$ ). The bill requires the Secretary of HHS to promulgate standard form contracts to accomplish the desired objective.

One might ask why the Domenici bill does not take the simpler approach of directly preempting state law with respect to medical injuries, relying on Congress's constitutional power to regulate interstate commerce. Nevertheless, although S. 1232 may seem to struggle to find nexuses for forcing individuals to accept new legal rights, the approach it adoptsdeeming or requiring certain agreements to exist-nods helpfully in the direction of consumer choice as expressed in private contracts. Although the bill would prescribe some very important choices by law, its reliance in other respects on the contractual character of consumer/provider/payer relationships is, as noted earlier, one of its main strengths. Adoption by Congress of a direct preemptive approach, assuming its constitutionality, might easily undercut not merely federalism but the basically private, contractual character of much American health care.

III

\section{Mandating Alternative Dispute Resolution While Allowing Flexibility in Its Design}

S. 1232 is a bold attempt to impose mandatory and binding ADR for the great majority of medical malpractice claims. But even though various procedural alternatives have been used in malpractice cases in the past, experience with binding ADR has been limited, and its utility is unproved. What then might justify the leap of faith in ADR that is inherent in the Domenici proposal?

\section{A. The Benefits of ADR}

There are many reasons why binding ADR might be considered an improvement over the current method of resolving malpractice claims. For example, the high cost of litigation in the courts strongly suggests that substantial cost savings could be achieved by shortening hearings and otherwise simplifying the litigation process. Similarly, binding ADR should be capable of speeding the final resolution of claims-a great benefit to claimants-by avoiding bottlenecks that exist in many court systems and by obviating most appeals. Mandatory ADR administered by selected ADR providers should also be capable of yielding results that are more reliable and more predictable, especially with respect to the amount of damages, than decisions of lay juries. Greater predictability of outcomes would seem in turn to facilitate more and fairer settlements, although it is also possible that the lower costs and quicker results associated with ADR would actually cause 
more cases to be litigated. In any event, it seems to us that Congress could reasonably conclude that, whatever the actual results of mandatory binding ADR in terms of cost, speed, and quality of claims resolution, they will probably be preferable on average to the results now being obtained. It must be admitted, nevertheless, that the Domenici proposal is based more on theory and instinct than on hard evidence-just as continued adherence to the jury system is justified primarily by tradition and the testimonials of trial lawyers.

Enthusiasm for mandatory binding ADR may also be justified by its potential for improving claimants' access to legal services and the legal system. ${ }^{16}$ Lower litigation costs could well translate into lower contingent-fee rates for plaintiffs' lawyers and into a greater willingness of some lawyers to accept cases in which the potential award is not large. Although malpractice reform is often seen only as harming potential plaintiffs, an ADR system might prove more receptive to valid claims, bringing more cases of negligence to light than does the current system. ${ }^{17}$ In addition, ADR services might advertise to attract claims and provide neutral experts, sparing claimants the cost of hiring their own expert witnesses. Even if the overall cost of medical liability would not decline under the Domenici bill, the public would almost certainly get better value for the money it spends and better protection against medical injuries.

An additional possible basis for sharing S. 1232's faith in mandatory ADR is belief in its strategy of creating a market for ADR services and affording competing ADR providers the power and flexibility they need to structure attractive programs. Although it might appear that such a market exists already and that any benefits of ADR can be realized by its voluntary use, experience reveals impediments to its widespread voluntary adoption. There are only limited opportunities, mostly in health maintenance organizations, for patients and providers to enter into binding agreements concerning the handling of future disputes. Moreover, once a dispute has arisen, the number of adversarial interests involved in the case, particularly the individual interests and biases of the lawyers concerned, make it exceedingly difficult for the parties to reach an agreement to use ADR. ${ }^{18}$ Thus, the current market for

16. A possible barrier to access by would-be claimants to a largely private ADR system is the cost of operating the system, which, unlike most costs of the judicial system, would not be borne publicly. S. 1232 would solve this problem in a unique and interesting way. While requiring the losing party to pay such costs, the bill would eliminate the potential access-limiting burden on unsuccessful claimants by requiring a losing claimant's attorney to pay them "if such attorney's fee for representing the claimant is contingent in whole or in part on achieving a successful outcome" $(\$ 3(f))$. Thus, the risk of ADR costs associated with unsuccessful claims would be shared by all claimants and finally borne by the successful ones-in the same way that the legal costs of unsuccessful claims are shared through the contingent-fee system.

17. The bill finds that "as many as 15 out of 16 persons injured due to medical negligence never get compensation through the current medical malpractice system" ( $\$ 2(a)(3))$. Authority for this assertion is found in Harvard Medical Practice Study, Patients, Doctors, and Lawyers: Medical Injury. Malpractice Litigation, and Patient Compensation in New York 6 (Harvard U Press, 1990).

18. See, for example, US Gen Acct'g Office, Medical Malpractice: Few Claims Resolved Through Michigan's Voluntary Arbitration Program (December 1990) (legislation to encourage voluntary binding 
ADR is afflicted by high transaction costs and market failures that often prevent the parties from reaching efficient agreements. The Domenici bill would take the radical step of presuming or requiring the existence of agreements to use ADR while leaving the parties free to specify the particulars of the ADR scheme if they find the arbitration framework specified in the statute to be unsuitable. We see this strategy as having few downside risks and as offering many benefits to litigants and the health care system as a whole.

\section{B. The Benefits of a Dynamic Market for ADR Services}

Under S. 1232, covered malpractice disputes would be resolved pursuant to rules promulgated by freestanding dispute resolution services selected by the parties. ${ }^{19}$ The bill's assumption that there will be a multiplicity of ADR providers operating in lieu of the monolithic court system is critical to understanding its potential impact. Prior proposals to use ADR in malpractice cases have either contemplated creation of a new adjudicative system under governmental auspices or specified in detail the arbitration procedures that must be used. The Domenici bill is distinctive in both tolerating a multiplicity of ADR services and allowing each service substantial freedom to develop and employ its own procedures.

Tolerating multiple providers may seem problematical in trading the existing court system, a known institutional commodity, for a collection of unknown entities. The growth of ADR in the past decade, however, has spawned a growing number of reputable private dispute resolution services. The existing pool of potential providers of ADR for malpractice cases and its potential for further growth should make the Domenici proposal feasible, particularly since the ADR requirement would apply only to health care provided, not claims filed, after its effective date $(\S 8(\mathrm{a}))$. Nevertheless, many fledgling ADR organizations have little experience in handling malpractice claims, and too sudden an influx of demand might produce poor performance. Also, providers and consumers might rush into agreements with unproved ADR providers or with the few already established services, thus discouraging entry by new (especially nonprofit) organizations. Organizations with vested interests in the outcomes of malpractice casessuch as trial lawyers' organizations or state medical societies-might be quickest to organize ADR services, raising questions about their neutrality.

arbitration produced only 247 actual arbitrations out of approximately 20,000 malpractice claims in thirteen years).

19. Under the bill, a claimant may initiate a claim by filing it with any certified ADR service and by providing notice to the health care provider against whom the claim is being made $(\S 3(\mathrm{~b})(2))$. If, however, there is an agreement to use a particular service, the claim must be filed with it (\$ 3(b)(3)). Provision is also made for claims against multiple providers where there are inconsistent agreements on which ADR service to use (\$3(b)(4)). Because the bill gives the claimant a free choice of ADR services in the absence of an agreement, it encourages providers to seek prior agreements designating a particular service. 
For these reasons, the bill's effective date might be delayed somewhat longer than is contemplated.

To address concerns about the neutrality and competence of ADR providers-both during the development of a malpractice ADR industry and after an industry has had time to develop-the bill limits use to ADR providers certified by the Secretary of Health and Human Services. ${ }^{20}$ The clear intention, however, is that the Secretary will certify as many services as meet the bill's relatively straightforward requirements $(\S \S 6(\mathrm{a})(2),(3))$.

Under the certification requirements, an applicant must demonstrate expertise in administering ADR procedures, employ methods of selecting arbitrators that insure their neutrality, and disclose its funding sources. Taken collectively, these requirements represent an enlightened approach to the challenge of ensuring high-quality ADR services while also encouraging innovation and competition. ${ }^{21}$

Employing multiple ADR providers would make little difference if the bill mandated detailed ADR procedures. The bill's basic approach, however, is to describe a rudimentary arbitration procedure for use when the parties have not agreed upon an alternative. This "default mode" arbitration procedure is only a backstop, not a legislatively prescribed ideal. The bill's rules governing the arbitration are minimal, requiring only that ADR providers' rules give the parties (1) a period of discovery, (2) a right to a hearing conducted before a three-person arbitration panel "with expertise in medical injury disputes," and (3) a right to a written decision rendered within six months after the claim was filed $(\S 6(\mathrm{a})(4))$. (All rights are waivable or variable if the parties agree, of course.) The bill's spartan approach is unusual; other proposals to employ ADR methods have attempted to define a "better way" to resolve malpractice disputes by anticipating all procedural questions that might arise.

The outward simplicity of S. 1232 masks a sophisticated policy decision to foster competition among ADR services, broad flexibility in the design and use of ADR methods, and implementation of reforms by private contract. Several points deserve mention. First, although the bill requires use of a three-person arbitration panel in the absence of an agreement to employ a different model, it is notable for not prescribing the specific make-up of the panel. Other proposals would require, for example, that an ADR panel include a health care professional. S. 1232 would leave a certified ADR service quite free to structure panels and selection processes as it sees fit.

20. The bill does permit the Secretary to waive the certification criteria for state-sponsored ADR services $(\S 6(a))$.

21. The bill also requires dispute resolution services to have procedures for providing governmental agencies responsible for disciplining health care providers with information "regarding evidence of medical injury and the causes of such injuries" $(\$ 6(a)(1))$. Currently, that reporting function is performed by liability insurers. See Ilene D. Johnson, Reports to the National Practitioner Data Bank, $265 \mathrm{~J}$ Am Med Ass'n 407, 407-08 (January 16, 1991) (description of federal reporting requirements). It is unclear whether the bill's reporting requirement is meant to supplement or replace existing systems. Duplicative reporting should of course be avoided. 
Second, the bill is notable in neither writing in nor excluding particular procedural reforms. Despite the obvious temptation to mandate currently fashionable procedural innovations, the bill would leave individual ADR providers unconstrained in many respects. Even in structuring the arbitration system to be used in default of an agreed-upon alternative, ADR services would have flexibility with respect to such matters as (1) selecting arbitrators; (2) assigning them to particular panels; (3) controlling the timing, amount, or type of discovery permitted; (4) requiring pre-hearing conferences; (5) using neutral expert witnesses; (6) prescribing the length of hearings; and (7) establishing evidentiary rules.

Another manifestation of the bill's receptivity to innovations is its unique requirement that an ADR provider demonstrate "an ability to advise parties to a dispute regarding alternatives to the basic dispute resolution approach and to carry out such alternative procedures" if the parties agree to their use (§6(a)(5)). Numerous consensual departures from the bill's default model of arbitration can be visualized. For example, requiring a panel of three arbitrators may add unnecessary expense in small-stakes cases or in cases involving only simple factual issues or a contest over the amount of damages. Parties also might agree to a shorter hearing than the ADR service's rules provide. In other cases, the parties could bifurcate the case and submit only one or more issues-liability, causation, or damages-to the arbitrators. The bill also clearly encourages ADR providers to advise the parties to consider such other ADR methods as mediation, nonbinding arbitration, early neutral evaluation, and summary jury trials, each one of which is available in a number of different formats. ${ }^{22}$ Not only would the bill permit customizing procedures for particular disputes, but it would actively promote such options by specifically requiring the ADR provider to possess expertise in using them. These affirmative recognitions of the benefits of diversity in ADR are well calculated to achieve the goal of efficiency in resolving malpractice claims.

The Domenici bill provides a welcome contrast to other ADR proposals that have offered merely a substitute vision of how malpractice cases should be resolved. These earlier ADR proposals, rather than inviting innovation, have in fact been more restrictive than the current system, which allows litigants at least theoretical freedom to control much of the conduct of the litigation or to negotiate a method of ADR. The Domenici proposal reveals a clear and justified preference for giving ADR providers and their clients maximum flexibility in resolving claims.

\section{IV}

\section{Inviting Consensual Modifications of Liability Rules}

Several other provisions in S. 1232 are equally consistent with the notion that consumers and providers of health services can safely exercise some choice with respect to their legal rights and obligations. These provisions

22. See, for example, Metzloff, 54 L \& Contemp Probs at 104-14 (cited in note 4). 
contemplate and explicitly invite privately negotiated variations in the substantive standards by which liability is determined. Section 3 of the bill provides that liability on all claims subject to its terms would be governed by state law except insofar as (1) the Secretary of HHS provides otherwise by regulation for federally reimbursed care or (2) an organized health plan serving federally supported subscribers contracts with them to provide care meeting a different standard ( $\$ 3(d)$ ). A similar provision, allowing the adoption of different standards for care rendered under tax-subsidized employee benefit plans, appears in section 4 . Under both sections 3 and 4, however, any alternative test for liability that is adopted would have to fall within one of several specified general categories.

The optional types of tests that could be used under S. 1232 for determining the compensability of injuries have significant implications for overall health policy. Each represents a different way of reducing liability risks under prevailing tort doctrine in order to facilitate responsible economizing in the provision of health services. Under section 4 of the bill, for example, health plans of private employers would be authorized to "specify an alternative standard to govern care rendered under the plan."23 Thus, the bill expressly confirms the contractual freedom of consumers, acting through private health plans, to elect a clearer, more cost-conscious, and possibly less demanding standard of care. Until this freedom is clearly recognized by the courts-as it generally is not today-consumers will be unable effectively to authorize physicians to depart from customary medical practice, which is the traditional benchmark for judging physician liability. Customary medical practice, in addition to being ill-defined and highly variable, has been shown to be scientifically or economically questionable in many instances. Thus, there are good reasons why consumers, physicians, and organized health plans might choose a different standard to govern liability for future medical injuries. ${ }^{24}$

Sections 3 and 4 of S. 1232 also authorize specification of the qualifications of expert witnesses who can testify as to whether the applicable standard of care was met in a given case $(\S 3(d)(2))$. This is a way in which the de jure standard of care might at least be made more predictable.

The Domenici bill further endorses private adoption of alternative liability tests by authorizing the incorporation by reference, in both public and private health plans, of practice guidelines certified by the Secretary of HHS $(\S 3(d)(1))$. Such guidelines are currently being developed by a wide variety

23. This option of specifying a clearer and possibly less demanding general standard of care would not, for some reason, be granted to the Secretary of HHS, however. Nor could private health plans adopt it for federal beneficiaries or federal employees who voluntarily enroll. This is almost the only substantive difference between sections 3 and 4 of the bill.

24. For a discussion of possible alternative formulations of the general standard of care that might be incorporated in private contracts as a way of escaping ill-defined and inappropriate standards that induce the practice of "defensive medicine," see Havighurst, Altering the Applicable Standard of Care, 49 L \& Contemp Probs 265, 267, 273 (Spring 1986) (suggesting "reasonable and prudent" practice as a test or possibly limiting liability to cases of "gross negligence," suitably defined). 
of professional and research organizations as a way of strengthening the scientific base of medical practice. The Secretary of HHS is charged in S. 1232 with certifying practice guidelines that appear to be objective and up to date and that are supported by proper documentation, including justifications of the choices made $(\S 6(\mathrm{~b})(1))$. The Secretary is to certify, not a single, official set of guidelines, ${ }^{25}$ but any guidelines that meet these general standards. If some of these guidelines take account of cost considerationsthat is, trade-offs between the marginal benefits and marginal costs of particular measures in particular circumstances-consumers will possess a whole new set of practical tools for making explicit, enforceable economizing choices in purchasing health services. ${ }^{26}$ Under S. 1232, these tools could also be used to assure physicians that economizing in accordance the contract would not expose them to tort liability.

S. 1232 authorizes still another type of voluntary reform of the medical malpractice system. Under its terms, both public and private health plans would be permitted to reject fault as the basis for liability and to substitute an arrangement by which certain injuries would be compensated automatically $(\S 3(d)(3))$. Such alternative methods of compensation must be certified by the Secretary, however. Certification criteria set forth in the bill seek to ensure that incentives to maintain the quality of care are preserved, presumably by requiring the premiums of provider-purchased insurance to be experience-rated to reflect the outcomes actually achieved $(\S 6(\mathrm{~b})(2))$. The bill would also require that the financial protection given consumers be "at least comparable, on an actuarial basis, to the legal protections they would otherwise enjoy." A number of proposals for "no-fault" compensation systems have been made in recent years. ${ }^{27}$ The Domenici bill is an invitation to the private sector to consider these options as replacements for the costly and dysfunctional legal system that now dictates patient/provider relationships.

The reason why the Domenici bill is so noteworthy for inviting contractual reforms of malpractice rights is that private contracts have not heretofore been commonly thought of as legitimate vehicles for altering legal rules in this area. ${ }^{28}$ Yet virtually all Americans are troubled by the high cost of state-of-

25. Although the Secretary may select a single set of guidelines to govern all care for which the federal government pays directly $(\S 3(\mathrm{~d})(1))$, his certification of guidelines for possible use by organized health plans would not be so restrictive. Even with respect to guidelines selected for federal programs, exceptions may be authorized by the Secretary where "geographic or other factors affecting the availability of resources to meet health care needs may warrant some variation from an otherwise uniform standard" (id).

26. For expositions of the notion that practice guidelines should be certified by government and used as tools for clarifying and perhaps modifying patient entitlements and provider and payer obligations, see Clark C. Havighurst, Practice Guidelines for Medical Care: The Policy Rationale, 34 St Louis LJ 777 (1990); Havighurst, 54 L \& Contemp Probs 87 (cited in note 4).

27. For example, Laurence R. Tancredi \& Randall R. Bovbjerg, Rethinking Responsibility for Patient Injury: Accelerated-Compensation Events, A Malpractice and Quality Reform Ripe for a Test, $54 \mathrm{~L}$ \& Contemp Probs 147 (Spring 1991).

28. See generally Symposium, Medical Malpractice: Can the Private Sector Find Relief?, 49 L \& Contemp Probs 1, 143-320 (Spring 1986). 
the-art health care and by the inability of many persons, including many employed persons, to obtain health care coverage at affordable prices. A major reason why good low-cost coverage is unavailable is the legal system's insistence on dictating a single standard to govern the health care of all citizens ${ }^{29}$ and its inability to define a standard that reflects essential trade-offs and induces efficient medical practice. Consumers, on the other hand, have been unable to specify in contracts precisely what they do and do not wish to purchase from health care providers on a prepaid basis. In addition to the immense practical difficulty of spelling out patient entitlements and provider duties in enforceable terms (a problem that practice guidelines may overcome in time), private contracts have generally not been viewed as useful instruments of consumer choice. Instead, they have been seen primarily as vehicles by which powerful payers or providers can exploit consumer ignorance and deny desirable care. Enactment of the Domenici bill would go far toward legitimizing private economizing initiatives that courts are now too inclined to view with suspicion. A Congress that does not want to take upon itself the responsibility for rationing health care to the American people ought to view private contracts as a welcome means of empowering federally subsidized consumers to make some economizing choices for themselves.

\section{CONCLUSION}

We have written this article in order to call wider attention to $\mathrm{S} .1232$, which we view as a notable new entry in what has heretofore promised to be an unexciting race to use the influence of the federal government to reduce the burdens of medical malpractice law on both consumers and providers of health care. We have presented the bill primarily as an invitation to private health plans to broker contracts between providers and consumers that customize the procedures and substantive rules to be used in determining liability for medical injuries. Instead of being bound by law to accept costly procedural and substantive rights of doubtful value and inefficient standards of medical care borrowed from the medical profession and made mandatory under applicable state law, parties to various health care arrangements would receive under S. 1232 strong encouragement to elect to be governed by a legal regime of their own making. The various alternative procedures and substantive rights among which they might choose would be made credible by the oversight provided by the Secretary of HHS under general certification criteria supplied in the bill.

S. 1232 may be too innovative to be enacted in its present form. On the other hand, we see immense potential for combining its encouragement of private reform of poorly designed, cost-increasing malpractice rights with other federal proposals that seek to make good-quality health care accessible

29. See generally John A. Siciliano, Wealth, Equity, and the Unitary Medical Malpractice Standard, 77 Va L Rev 439 (1991). 
to all Americans at reasonable cost. Only if private economizing choices of the kind visualized here are facilitated and accepted by the legal system will the nation's future health care bill accurately reflect consumers' individual willingness, and the nation's collective ability, to pay. 


\section{APPENDIX}

Sections 3 and 6 of S. 1232, 102d Cong., 1ST Sess (1991)

\section{SEC. 3. FEDERAL MEDICAL DISPUTE RESOLUTION PROGRAM.}

(a) AGREEMENT TO PARTICIPATE.-Any person accepting or providing health care to be paid for, in whole or in part, directly or indirectly, with funds made available under the Social Security Act, the Public Health Service Act, or any other Federal Act shall be deemed to have agreed to participate in the Federal medical dispute resolution program established under this Act for the purpose of fairly and quickly resolving claims against health care providers for personal injury arising from care rendered under such Acts. Such agreement to participate shall be binding on any person making such a claim and shall be enforceable in any court of competent jurisdiction.

(b) MANDATORY RESOLUTION OF CLAIMS THROUGH CERTIFIED DISPUTE RESOLUTION SERVICE.-

(1) REQUIREMENT.-When an agreement is deemed to exist under subsection (a), any claim of the type referred to in that subsection that is not settled voluntarily by the parties thereto shall be resolved only through a dispute resolution service that has been certified under section 6.

(2) PROCEDURES.-A person having a claim of the type referred to in subsection (a) may initiate the procedures to resolve such claim through a dispute resolution service by-

(A) filing a claim with a dispute resolution service then appearing on the applicable list of such services maintained by the Secretary of Health and Human Services under section 6; and

(B) providing notice of such filing ... to the provider or providers against whom the claim is made.

(3) AGREEMENT TO USE SPECIFIC SERVICE.- If the person filing a claim under this section and the provider against whom such claim is filed agree or have previously agreed to use a particular dispute resolution service to resolve such claim, the claim shall be filed with that service.

(4) CLAIMS AGAINST MORE THAN ONE PROVIDER.-If a claim is made against more than one provider, such providers shall have not more than 30 days to agree that the claim will be resolved by any dispute resolution service to which the claimant has agreed with any one of such providers.

(5) RESOLUTION.-Once properly filed, a claim under this section shall be resolved by the dispute resolution service selected, under procedures prescribed by such service. The decision of the dispute resolution service with respect to a claim under this section shall be final and not subject to further review by any court, except that a party to a 
dispute may obtain review of the decision on any of the following grounds in any court of competent jurisdiction in the State wherein the decision was made:

(A) The award was procured by corruption, fraud, or other undue means.

(B) There was evident partiality or corruption on the part of the arbiter.

(C) The arbiter was guilty of misconduct in refusing to postpone the hearing, upon sufficient cause shown, or in refusing to hear evidence pertinent and material to the controversy, or of any misbehavior by which the rights of any party were prejudiced.

(D) The arbiter exceeded its powers or so imperfectly executed them that a final and definite award upon the claim was not made.

Where an award is vacated under this paragraph, the court shall direct that the matter shall be reheard by another arbiter under the procedures prescribed by the dispute resolution service.

(c) LIMITATIONS.-No claim of the type referred to in subsection (a) may be filed with a dispute resolution service after the expiration of any applicable time limitation as prescribed in State law, and in no event, except in the case of fraudulent concealment of relevant facts by the provider against whom the claim is made, may such a claim be brought in any forum more than 8 years after the date of the occurrence of the incident that gave rise to the claim.

(d) STANDARD FOR IMPOSING LIABILITY.- Liability for any claim that is subject to resolution under subsection (b) shall be determined under the standard of care prescribed under applicable State law, except that the Secretary of Health and Human Services may determine . . . and any organized health plan in which beneficiaries may voluntarily enroll may provide by contract, that-

(1) particular services shall be rendered in accordance with identified medical practice guidelines that have been certified pursuant to section 6(b), in which case such guidelines shall, to the extent applicable, be deemed to supply the standard of care to be employed in determining liability (the Secretary may determine that geographic or other factors affecting the availability of resources to meet health care needs may warrant some variation from an otherwise uniform standard supplied by such guidelines);

(2) any expert witnesses testifying as to whether the applicable standard of care was met must possess specified qualifications; or

(3) certain personal injuries and other losses resulting from specified services or procedures shall be compensated without regard to provider fault if such alternative method of compensation has been certified by the Secretary pursuant to section 6(b). 
(e) DAMAGES.-When a claim that is subject to resolution under subsection (b) results in a finding of liability, the damages awarded to the claimant shall be determined and awarded as follows-

(1) awards for noneconomic damages shall be limited to $\$ 250,000 \ldots$;

(2) awards shall be reduced for any collateral source payments to which the patient is entitled for the medical injury for which the claim was filed;

(3) in the case of an award in excess of $\$ 100,000$, claimants shall accept periodic payment of the amount of such awards that are intended to compensate the claimant for damages expected to be incurred in the future such as lost income and medical expenses; and

(4) an award for punitive damages shall not be paid to the claimant, but shall instead be paid to the State if the State has submitted a plan to the Secretary of Health and Human Services, and the Secretary has approved such a plan, to use such funds to improve the monitoring, disciplining, and educating of health care providers in the State to ensure they meet standards of competency.

(f) COSTS.-The party against whom a claim, that is subject to resolution under subsection (b), is substantially resolved (an issue to be expressly determined in resolving the dispute) shall pay the charges assessed by the dispute resolution service for resolving the claim (if any such charges are assessed), except that-

(1) any such charges payable by the claimant shall be paid in fact by the claimant's attorney if such attorney's fee for representing the claimant is contingent in whole or in part on achieving a successful outcome; and

(2) a claimant who is not represented by an attorney and who demonstrates an inability to pay such charges (according to criteria specified by the Secretary in regulations) shall be entitled to have liability for such charges (including any filing fees) waived by the dispute resolution service.

\section{SEC. 6. CERTIFICATION.}

(a) ALTERNATIVE DISPUTE RESOLUTION SERVICES.-Not later than 12 months after the date of enactment of this Act, the Secretary of Health and Human Services shall promulgate regulations that establish the criteria and procedures by which the Secretary (or persons to whom the Secretary has delegated such authority) will determine whether or not to certify an alternative dispute resolution service, except that the Secretary may waive such criteria and procedures in certifying dispute resolution services sponsored by the States. The regulations shall include (but are not limited to) provisions requiring such services to-

(1) have procedures in place for providing to the Federal and State agencies responsible for monitoring or disciplining health care providers 
standardized information and data regarding evidence of medical injury and the causes of such injuries;

(2) maintain a roster of qualified and independent arbitrators willing to resolve medical injury disputes pursuant to the rules established by the service;

(3) demonstrate neutrality by disclosing funding sources and selection methods used for obtaining arbitrators in resolving medical injury disputes;

(4) demonstrate administrative expertise and an ability to conduct dispute resolution procedures that is consistent with a basic dispute resolution procedure which shall include-

(A) decisionmaking by a three person arbitration panel with expertise in medical injury disputes;

(B) a period to permit the discovery of evidence;

(C) the right to a hearing;

(D) the right to a decision not later than 6 months after the date on which the claim was filed; and

(E) the right to a written decision; and

(5) require administrative expertise and an ability to advise parties to a dispute regarding alternatives to the basic dispute resolution approach and to carry out such alternative procedures if all parties to a dispute agree to one of the alternative procedures.

(b) STANDARDS FOR IMPOSING LIABILITY.-Not later than 12 months after the date of enactment of this Act, the Secretary of Health and Human Services shall promulgate regulations that-

(1) establish the criteria to be used for the certification of medical practice guidelines by the Secretary (or persons to whom the Secretary has delegated such authority), including criteria to ensure that such guidelines-

(A) reflect up-to-date scientific learning and the judgment of objective experts;

(B) are supported by proper documentation; and

(C) are accompanied by justifications for the standards established; and

(2) establish the criteria to be used for the certification by the Secretary (or persons to whom the Secretary has delegated such authority) of alternative methods of compensating personal injuries and other losses without regard to provider fault, including criteria to ensure that such alternative methods would-

(A) be administered fairly and efficiently;

(B) preserve incentives to maintain the quality of care; and

(C) generally give health care consumers financial protection that is at least comparable, on an actuarial basis, to the legal protections they would otherwise enjoy. 
(c) OTHER REGULATIONS.-Not later than 12 months after the date of enactment of this Act, the Secretary of Health and Human Services shall promulgate other regulations necessary to carry out this Act. 
